Article

\title{
Mercury(II)-Catalyzed Cleavage, Isomerization and Depurination of RNA and DNA Model Compounds and Desulfurization of Their Phosphoromonothioate Analogs
}

\author{
Lange Yakubu Saleh, Mikko Ora and Tuomas Lönnberg *(1) \\ Department of Chemistry, University of Turku, 20014 Turku, Finland; lange.saleh@utu.fi (L.Y.S.); \\ mikora@utu.fi (M.O.) \\ * Correspondence: tuanlo@utu.fi
}

Received: 30 January 2020; Accepted: 9 February 2020; Published: 11 February 2020

\begin{abstract}
The potential of $\mathrm{Hg}(\mathrm{II})$, a metal ion so-far overlooked in the development of artificial nucleases, to cleave RNA and DNA has been assessed. Accordingly, $\mathrm{Hg}(\mathrm{II})$-promoted cleavage and isomerization of the RNA model compound adenylyl- $3^{\prime}, 5^{\prime}-\left(2^{\prime}, 3^{\prime}-O\right.$-methyleneadenosine $)$ and depurination of $2^{\prime}$-deoxyadenosine were followed by HPLC as a function of $\mathrm{pH}$ (5.0-6.0) and the desulfurization of both diastereomers of the phosphoromonothioate analog of adenylyl-3', $5^{\prime}-\left(2^{\prime}, 3^{\prime}-O\right.$-methyleneadenosine $)$ at a single $\mathrm{pH}(6.9)$. At $5 \mathrm{mM}$ [Hg(II)], cleavage of the RNA model compound was accelerated by two orders of magnitude at the low and by one order of magnitude at the high end of the $\mathrm{pH}$ range. Between 0 and $5 \mathrm{mM}[\mathrm{Hg}(\mathrm{II})]$, the cleavage rate showed a sigmoidal dependence on $[\mathrm{Hg}(\mathrm{II})]$, suggesting the participation of more than one $\mathrm{Hg}$ (II) in the reaction. Isomerization and depurination were also facilitated by $\mathrm{Hg}$ (II), but much more modestly than cleavage, less than 2-fold over the entire $\mathrm{pH}$ range studied. Phosphoromonothioate desulfurization was by far the most susceptible reaction to $\mathrm{Hg}$ (II) catalysis, being accelerated by more than four orders of magnitude.
\end{abstract}

Keywords: mercury; catalysis; RNA; DNA; phosphodiester; phosphoromonothioate; cleavage; depurination; desulfurization

\section{Introduction}

Metal ion-catalyzed cleavage of both RNA and DNA phosphodiester linkages has been investigated extensively to understand the mechanism of action of natural nucleases (including ribozymes) [1-5], as well as to develop artificial ones [6-10]. Comparative studies with phosphodiester and phosphorothioate model compounds have been instrumental in revealing coordination of catalytically important metal ions to the scissile linkage [11-16]. The catalytic activities of various metal ions reflect their binding affinities to oxygen and sulfur, with hard metal ions being more efficient in the cleavage of phosphates and soft ones in the cleavage of phosphorothioates. $\mathrm{Hg}$ (II) lies at the thiophilic end of the spectrum and has indeed been reported to affect very rapid cleavage and desulfurization of RNA phosphorothioate linkages while leaving phosphodiester linkages largely intact [17]. On the other hand, the very low $\mathrm{p} K_{\mathrm{a}}$ of an aqua ligand of $\mathrm{Hg}$ (II) [18] would predict high activity also in the cleavage of RNA phosphodiester linkages [3]. Interestingly, $\mathrm{Hg}(\mathrm{II})$ is also the only metal ion reported to accelerate depurination [19], potentially offering a novel approach for the cleavage of DNA. However, to the best of our knowledge, detailed kinetic data on the catalytic effect of $\mathrm{Hg}$ (II) on the cleavage, isomerization or depurination of nucleosides and dinucleoside phosphodiesters is not available. 
We report herein a detailed kinetic study on the cleavage and isomerization of adenylyl-3', $5^{\prime}-\left(2^{\prime}, 3^{\prime}-O-\right.$-methyleneadenosine $)$ and the desulfurization of the $R_{\mathrm{p}}$ and $S_{\mathrm{p}}$ diastereomers of its phosphoromonothioate analog, as well as the depurination of $2^{\prime}$-deoxyadenosine in the presence and absence of $\mathrm{Hg}(\mathrm{II})$. Adenine was chosen as the base moiety for its relatively rapid depurination. The permanent methylene protection on the $5^{\prime}$-linked nucleoside, in turn, facilitates analysis of the cleavage reaction by ensuring that distinct sets of products would be obtained from the $3^{\prime}$ - and $5^{\prime}$-linked nucleosides even after possible dephosphorylation. The greatest accelerations by $\mathrm{Hg}$ (II) were observed with phosphoromonothioate desulfurization and phosphodiester cleavage, the reactions being four and two orders of magnitude faster in the presence of $\mathrm{Hg}$ (II) than in the absence thereof. Much more modest (less than two-fold) accelerations were observed with depurination and isomerization reactions.

\section{Results and Discussion}

\subsection{Synthesis}

Phosphodiester 1a and its phosphoromonothioate analog 2a (as $R_{\mathrm{P}}$ and $S_{\mathrm{P}}$ diastereomers) were prepared as described in Scheme 1 by displacing the diisopropylamino ligand of an appropriately protected adenosine $3^{\prime}$-(2-cyanoethyl- $N, N$-diisopropylphosphoramidite) by $N^{6}, N^{6}$-dibenzoyl-2', $3^{\prime}$-O-methyleneadenosine (3), using 5-(benzylthio)- $1 H$-tetrazole as an activator. The phosphite triester formed was oxidized to either phosphate or thiophosphate ester by treatment with either elemental iodine in a mixture of tetrahydrofuran, water and 2,6-lutidine or elemental sulfur in dicholoromethane. The cyanoethyl group was removed in a mixture of pyridine and $\mathrm{Et}_{3} \mathrm{~N}$ and the benzoyl groups in a mixture of aqueous ammonia and methylamine to afford intermediates 4 and 5 . Finally, removal of tert-butyldimethylsilyl and dimethoxytrityl groups by treatment with triethylamine trihydrofluoride, followed by RP-HPLC purification, gave the desired products 1a and 2a. The two diastereomers of the phosphorothioate product $2 \mathrm{a}$ were separable by RP-HPLC and were assigned absolute configurations based on their ${ }^{31} \mathrm{P}$ NMR chemical shifts, as described in the literature [20].
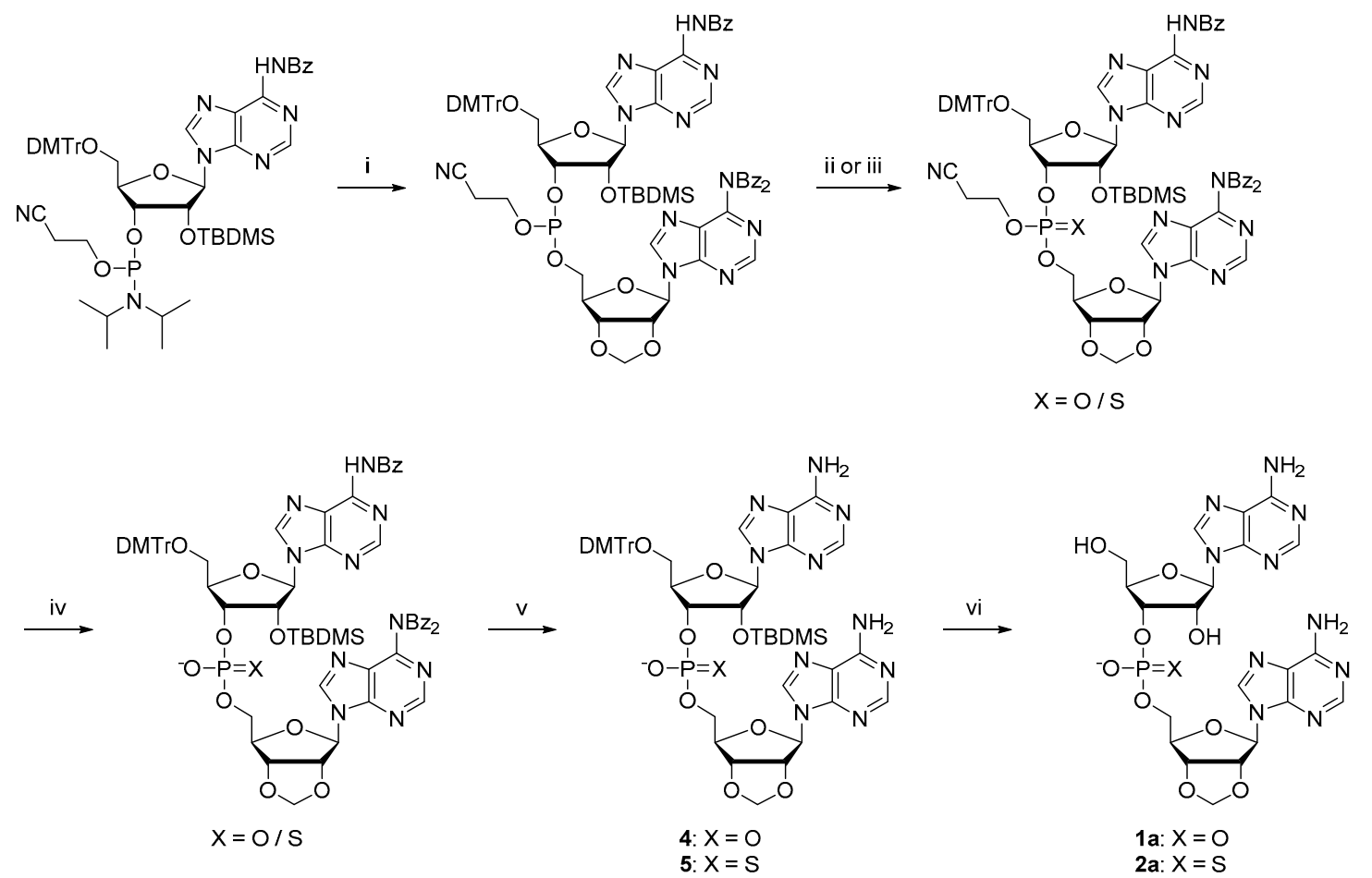

Scheme 1. Synthesis of the dinucleoside monophosphate and phosphorothioate model compounds 1a and 2a. Reagents and conditions: (i) 3,5-(benzylthio)- $1 \mathrm{H}$-tetrazole, $\mathrm{MeCN}$; (ii) $\mathrm{I}_{2}$, $\mathrm{THF}, \mathrm{H}_{2} \mathrm{O}, 2$,6-lutidine; (iii) $\mathrm{S}_{8}, \mathrm{CH}_{2} \mathrm{Cl}_{2}$; (iv) $\mathrm{Et}_{3} \mathrm{~N}$, pyridine; (v) $\mathrm{NH}_{3}, \mathrm{MeNH}_{2}, \mathrm{H}_{2} \mathrm{O}$; (vi) $\mathrm{Et}_{3} \mathrm{~N} \bullet 3 \mathrm{HF}, \mathrm{CH}_{2} \mathrm{Cl}_{2}$. 


\subsection{Reaction Kinetics}

\subsubsection{Cleavage and Isomerization of Adenylyl-3', $5^{\prime}-\left(2^{\prime}, 3^{\prime}-O-M e t h y l e n e a d e n o s i n e\right)(\mathbf{1 a})$}

Hydrolytic reactions of the phosphodiester model compound 1a were followed by RP-HPLC at 90 ${ }^{\circ} \mathrm{C}$ over a $\mathrm{pH}$ range of 5.0-6.0 (30 mM MES buffer) and at a constant ionic strength of $0.10 \mathrm{M}$ (adjusted with sodium nitrate). At $\mathrm{pH} 6.0$, the reactions were also followed at various $\mathrm{Hg}$ (II) concentrations ranging from 0 to $5 \mathrm{mM}$. The narrow $\mathrm{pH}$ range was dictated by the low solubility of $\mathrm{Hg}$ (II) under more alkaline conditions. Prior to analysis, sodium chloride was added to the samples to precipitate $\mathrm{Hg}$ (II) out as the tetrachlorido complex.

Over the $\mathrm{pH}$ and $[\mathrm{Hg}(\mathrm{II})]$ range studied, the expected reactions, namely, cleavage to adenosine $2^{\prime}, 3^{\prime}$-cyclic monophosphate (cAMP) and $2^{\prime}, 3^{\prime}$-O-methyleneadenosine (6) and isomerization to adenylyl-2', $5^{\prime}-\left(2^{\prime}, 3^{\prime}\right.$-O-methyleneadenosine) (1b), predominated (Scheme $2, k_{1}, k_{2}$ and $k_{-2}$, respectively). cAMP was further converted to adenosine without accumulation of $2^{\prime}$ - and $3^{\prime}$-monophosphate intermediates. Finally, depurination of the various adenosine derivatives was also observed. The rates of these last two reactions were, however, too slow to be quantified reliably.

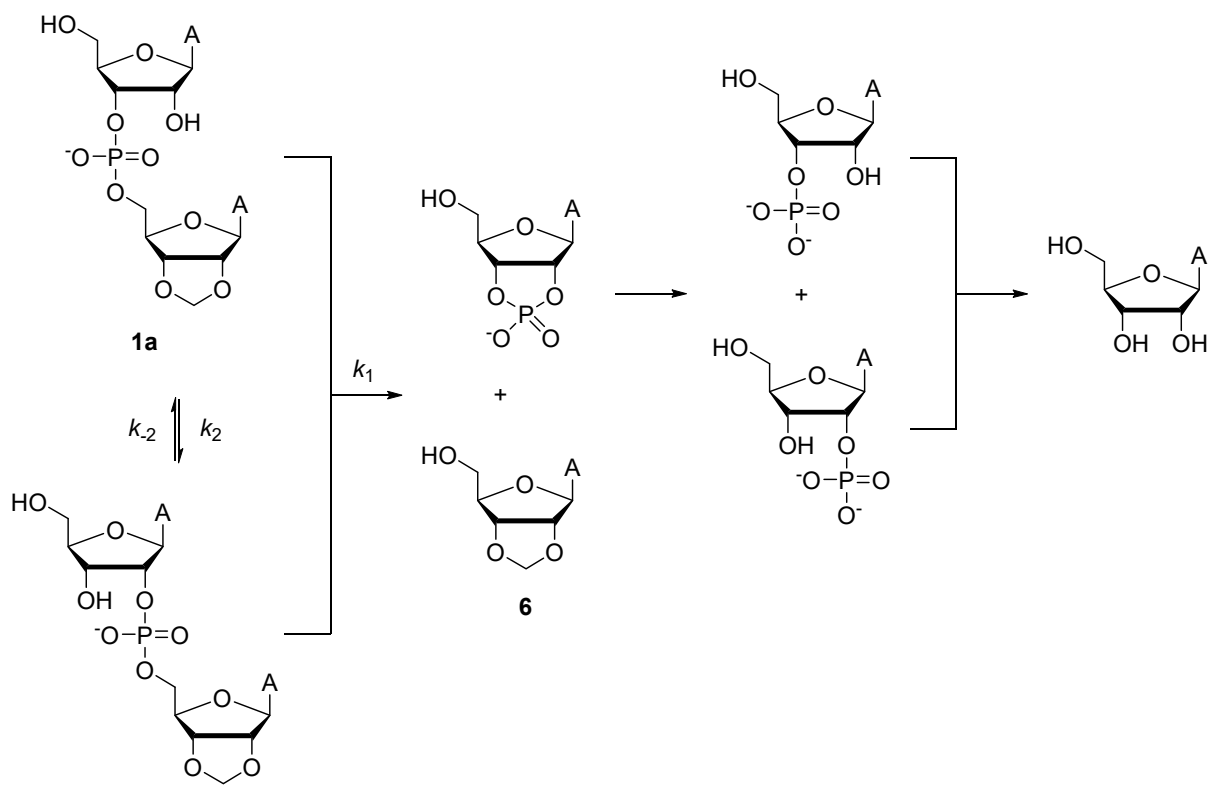

$1 \mathrm{~b}$

Scheme 2. Hydrolytic reaction pathways of $\mathbf{1 a}$ and $\mathbf{1 b}$.

The dependence of the rate of cleavage and isomerization of $\mathbf{1 a}$ on [Hg(II)] was studied over a concentration range of $0-5 \mathrm{mM}$ at $\mathrm{pH} 6.0$ (Figure 1). Both reactions exhibited a similar pattern of $[\mathrm{Hg}(\mathrm{II})]$-dependence of rate at low $[\mathrm{Hg}(\mathrm{II})]$ and leveling-off at high $[\mathrm{Hg}(\mathrm{II})]$, and in both cases, the dependence of the observed pseudo first-order rate constant on $[\mathrm{Hg}(\mathrm{II})]$ may be expressed by Equation (1).

$$
k^{o b s}=k^{0}+\frac{k^{H g}[\mathrm{Hg}]^{n}}{K_{d}^{n}+[\mathrm{Hg}]^{n}},
$$

$k^{0}$ and $k^{\mathrm{Hg}}$ are the first- and second-order rate constants for the $\mathrm{Hg}$ (II)-independent and $\mathrm{Hg}$ (II) catalyzed reactions, respectively, $K_{\mathrm{d}}$ is the dissociation constant of the reactive complex and $n$ is the reaction order with respect to $\mathrm{Hg}(\mathrm{II})$ ion. The rate constants obtained by non-linear least-squares fitting of the experimental data to Equation (1) are summarized in Table 1. 


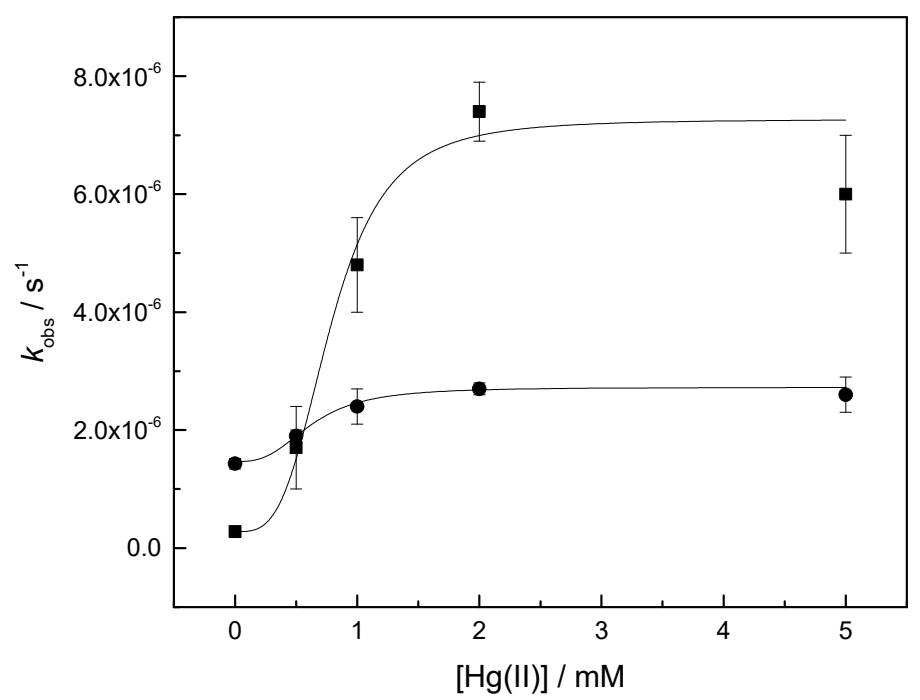

Figure 1. $[\mathrm{Hg}(\mathrm{II})]$-dependence of the rate of cleavage $\left(k_{1}, \boldsymbol{\square}\right)$ and isomerization $\left(k_{2}+k_{-2}, \bullet\right)$ of $\mathbf{1 a}$ and 1b; $T=90^{\circ} \mathrm{C} ; \mathrm{pH}=6.0 ;[$ buffer $]=30 \mathrm{mM} ;\left(\mathrm{NaNO}_{3}\right)=100 \mathrm{mM}$.

Table 1. Kinetic parameters for $\mathrm{Hg}(\mathrm{II})$-catalyzed cleavage $\left(k_{1}\right)$ and isomerization $\left(k_{2}+k_{-2}\right)$ of $\mathbf{1 a}$ and $\mathbf{1 b}$; $T=90^{\circ} \mathrm{C} ; \mathrm{pH}=6.0 ;[$ buffer $]=30 \mathrm{mM} ;\left(\mathrm{NaNO}_{3}\right)=100 \mathrm{mM}$.

\begin{tabular}{cccc}
\hline & $\boldsymbol{k}^{\mathbf{0}} / \mathbf{1 0}^{\mathbf{- 7}} \mathbf{s}^{\mathbf{- 1}}$ & $\boldsymbol{k}^{\mathbf{H g}} / \mathbf{1 0}^{-\mathbf{6}} \mathbf{M}^{-\mathbf{n}} \mathbf{s}^{-\mathbf{1}}$ & $\boldsymbol{n}$ \\
\hline$k_{1}$ & $2.8 \pm 0.1$ & $7 \pm 2$ & $3 \pm 10$ \\
$k_{2}+k_{-2}$ & $14 \pm 1$ & $1.3 \pm 0.2$ & $3 \pm 6$ \\
\hline
\end{tabular}

The rate constants for the $\mathrm{Hg}(\mathrm{II})$-independent reactions were consistent with those reported previously for similar model compounds under the same conditions [21]. The observation that cleavage is catalyzed more efficiently than isomerization $\left(k^{\mathrm{Hg}}=7.0\right.$ and $1.3 \times 10^{-6} \mathrm{M}^{-\mathrm{n}} \mathrm{s}^{-1}$, respectively) is also in line with previous reports on catalysis by other metal ions [11], and suggests that $\mathrm{Hg}(\mathrm{II})$ exerts its catalytic effect mainly by assisting in the departure of the $5^{\prime}$-linked nucleoside. This assistance could take the form of either direct coordination of $\mathrm{Hg}$ (II) to the departing oxygen or proton transfer from an aqua ligand. The dissociation constants for the reactive complex were very similar for both cleavage and isomerization $\left(K_{\mathrm{d}}=0.8\right.$ and $0.63 \mathrm{mM}$, respectively) and comparable to the respective value determined for the $\mathrm{Hg}(\mathrm{II})$-adenosine complex [22]. Adenosine $5^{\prime}$-monophosphate, on the other hand, has been reported to form indirect chelates with divalent transition metal ions, with an aqua ligand of an N7-coordinated metal ion hydrogen-bonded to the phosphate [23-25]. Such a binding mode seems likely also in the present case and would be consistent with the observed catalysis. Finally, fitting of the experimental data suggested a third-order dependence of the rate of cleavage and isomerization on $\mathrm{Hg}$ (II). This value is highly uncertain, but the sigmoidal plots obtained for both reactions would seem to indicate the participation of more than one $\mathrm{Hg}(\mathrm{II})$ ions. Participation of two metal ions has been demonstrated with several other metals, and the most efficient metal catalysts for the cleavage of RNA phosphodiester linkages are, indeed, dinuclear complexes [26-33].

In the absence of $\mathrm{Hg}(\mathrm{II})$, mutual isomerization of $\mathbf{1 a}$ and $\mathbf{1} \mathbf{b}$ was $\mathrm{pH}$-independent, whereas, cleavage to monomeric products was gradually turning first-order in hydroxide ion on increasing $\mathrm{pH}$ (Figure 2). Isomerization was an order of magnitude faster than cleavage, allowing $k_{2}$ and $k_{-2}$ to be determined based on the relative concentrations of $\mathbf{1 a}$ and $\mathbf{1 b}$ at equilibrium. The ratio of [1a] to [1b] approached unity, corresponding to essentially equal values for $k_{2}$ and $k_{-2}$. With cleavage, 
the contributions of $\mathrm{pH}$-independent and hydroxide ion catalyzed reactions to the observed pseudo first-order rate constant may be expressed by Equation (2).

$$
k_{1}^{o b s}=k_{1}^{W}+k_{1}^{O H} \frac{K_{W}}{\left[\mathrm{H}^{+}\right]^{\prime}}
$$

$K_{\mathrm{W}}$ is the ion product of water under the experimental conditions $\left(6.2 \times 10^{-13} \mathrm{M}^{2}\right)$ and $k_{1}{ }^{\mathrm{W}}$ and $k_{1} \mathrm{OH}$ the first- and second-order rate constants for the $\mathrm{pH}$-independent and hydroxide ion catalyzed reactions, respectively. The rate constants obtained (Table 2) were in good agreement with those reported previously for similar model compounds [21].

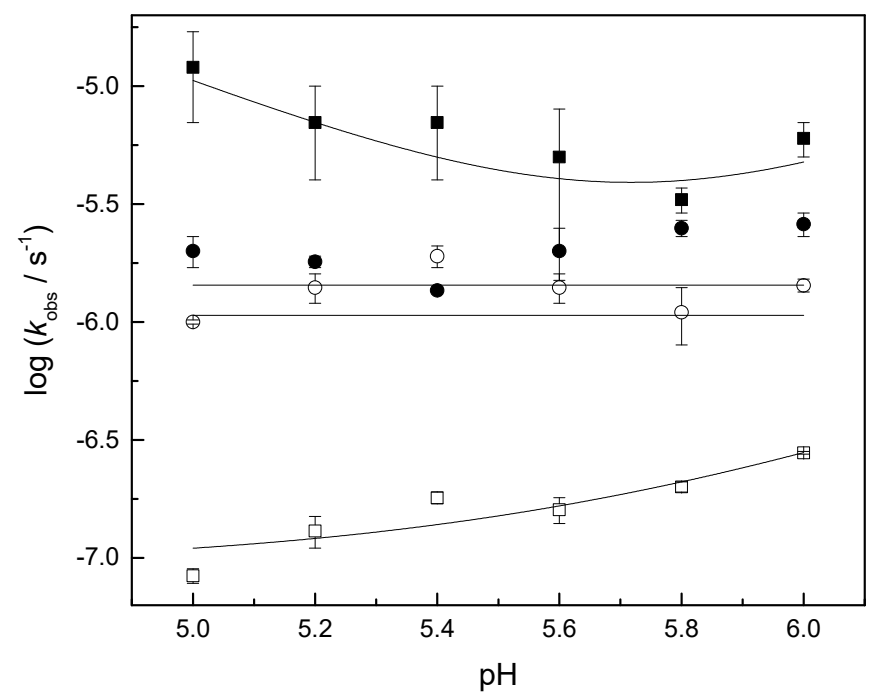

Figure 2. $\mathrm{pH}$-rate profiles for the cleavage $\left(k_{1}\right.$, squares) and isomerization $\left(k_{2}+k_{-2}\right.$, circles) of $\mathbf{1 a}$ in the absence (open symbols) and presence (filled symbols) of $\mathrm{Hg}(\mathrm{II}) ; \mathrm{T}=90^{\circ} \mathrm{C} ;[\mathrm{Hg}(\mathrm{II})]=0 / 5 \mathrm{mM}$; [buffer $]=$ $30 \mathrm{mM} ;\left(\mathrm{NaNO}_{3}\right)=100 \mathrm{mM}$.

Table 2. Rate constants for the partial reactions contributing to the cleavage and isomerization of $\mathbf{1 a}$ and $\mathbf{1 b} ; \mathrm{T}=90^{\circ} \mathrm{C} ;[\mathrm{Hg}(\mathrm{II})]=0 / 5 \mathrm{mM} ;[$ buffer $]=30 \mathrm{mM} ;\left(\mathrm{NaNO}_{3}\right)=100 \mathrm{mM}$.

\begin{tabular}{ccccccc}
\hline \multirow{2}{*}{$\mathbf{H g}(\mathbf{I I})$} & \multicolumn{2}{c}{$\boldsymbol{k}^{\mathbf{H}} / \mathbf{M}^{\mathbf{- 1}} \mathbf{s}^{\mathbf{- 1}}$} & \multicolumn{2}{c}{$\boldsymbol{k}^{\mathbf{W}} / \mathbf{1 0}^{-\mathbf{8}} \mathbf{s}^{\mathbf{- 1}}$} & \multicolumn{2}{c}{$\boldsymbol{k}^{\mathrm{OH}} / \mathbf{M}^{-\mathbf{1}} \mathbf{s}^{\mathbf{- 1}}$} \\
\cline { 2 - 7 } & - & + & - & + & - & + \\
\hline$k_{1}$ & n.a. & $1.0 \pm 0.3$ & $9 \pm 2$ & n.a. & $0.30 \pm 0.04$ & $6 \pm 1$ \\
$k_{2}+k_{-2}$ & n.a. & n.a. & $107 \pm 8$ & $140 \pm 10$ & n.a. & n.a. \\
$k_{2}$ & n.a. & n.a. & $59 \pm 4$ & n.a. & n.a. & n.a. \\
$k_{-2}$ & n.a. & n.a. & $48 \pm 4$ & n.a. & n.a. & n.a. \\
\hline
\end{tabular}

At a saturating $(5.0 \mathrm{mM})$ concentration of $\mathrm{Hg}(\mathrm{II})$, mutual isomerization of $\mathbf{1 a}$ and $\mathbf{1 b}$ was $\mathrm{pH}$-independent and only marginally faster than in the absence of $\mathrm{Hg}$ (II) (Figure 2). Cleavage, in turn, appeared to be first-order in hydronium ion at low $\mathrm{pH}$ and first-order in hydroxide ion at high $\mathrm{pH}$, the rate acceleration by $\mathrm{Hg}$ (II) ranging from 140 -fold at $\mathrm{pH} 5.0$ to 20 -fold at $\mathrm{pH}$ 6.0. Comparable acceleration has been reported previously for other divalent transition metal ions, such as $\mathrm{Zn}$ (II) [34]. Over the entire $\mathrm{pH}$ range studied, cleavage was also significantly faster than isomerization and the $2^{\prime}$-isomer $\mathbf{1 b}$ did not accumulate sufficiently for reliable determination of $k_{2}$ and $k_{-2}$. The observed pseudo first-order rate constant for the cleavage reaction was broken down to contributions of hydronium and hydroxide ion catalyzed reactions by Equation (3).

$$
k_{1}^{o b s}=k_{1}^{H}\left[\mathrm{H}^{+}\right]+k_{1}^{O H} \frac{K_{W}}{\left[\mathrm{H}^{+}\right]^{\prime}}
$$


$K_{\mathrm{W}}$ is the ion product of water under the experimental conditions $\left(6.2 \times 10^{-13} \mathrm{M}^{2}\right)$ and $k_{1}{ }^{\mathrm{H}}$ and $k_{1} \mathrm{OH}$ the second-order rate constants for the hydronium and hydroxide ion catalyzed reactions, respectively. Rate constants obtained for all partial reactions are summarized in Table 2.

\subsubsection{Depurination of $2^{\prime}$-Deoxyadenosine}

Depurination of 2'-deoxyadenosine was studied under the same conditions as the hydrolytic reactions of $\mathbf{1 a}$ and $\mathbf{1 b}$. Conversion of $2^{\prime}$-deoxyadenosine to adenine and nonchromophoric products (Scheme 3, $k_{3}$ ) was the only reaction over the entire $\mathrm{pH}$ range studied and regardless of the presence of $\mathrm{Hg}(\mathrm{II})$. The reaction was first-order in hydronium ion both in the absence and presence of $\mathrm{Hg}$ (II) (Figure 3), the second-order rate constants being $k_{3}{ }^{\mathrm{H}}=1.16 \pm 0.06$ and $2.2 \pm 0.2 \mathrm{M}^{-1} \mathrm{~s}^{-1}$, respectively. Similar modest acceleration by $\mathrm{Hg}$ (II) has been reportedly previously for 9-(1-ethoxyethyl)purine and attributed to additive electron-withdrawing effects of simultaneous protonation at $\mathrm{N} 1$ and $\mathrm{Hg}$ (II) coordination at N7 [19].

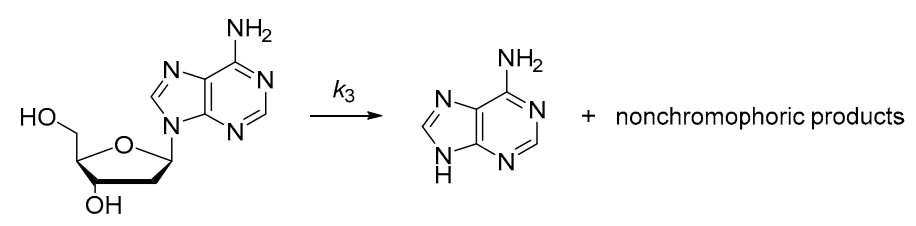

Scheme 3. Depurination of 2'-deoxyadenosine.

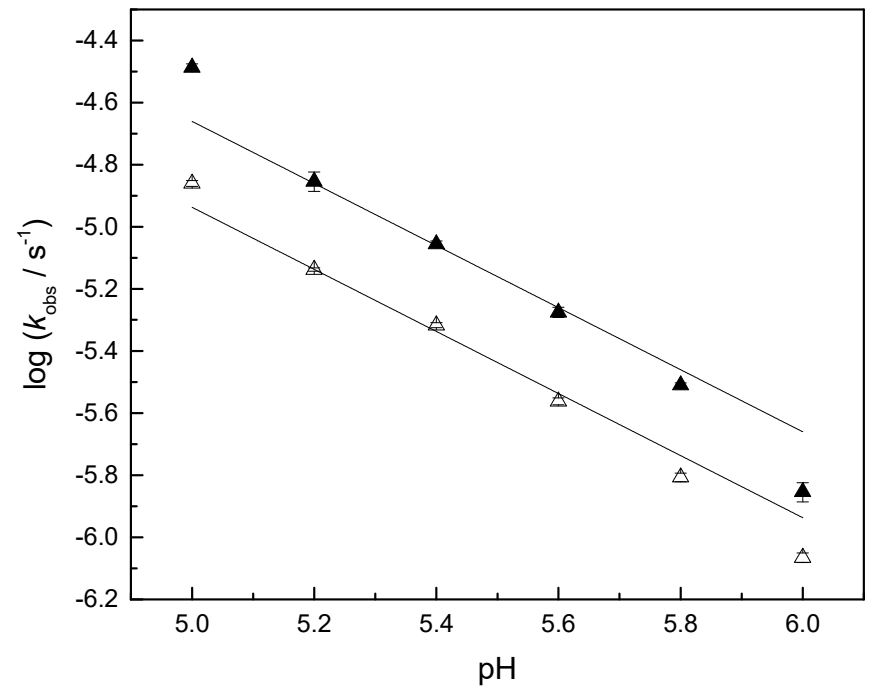

Figure 3. $\mathrm{pH}$-rate profiles for the depurination $\left(k_{3}\right)$ of $2^{\prime}$-deoxyadenosine in the absence (open triangles) and presence (filled triangles) of $\mathrm{Hg}(\mathrm{II}) ; \mathrm{T}=90^{\circ} \mathrm{C} ;[\mathrm{Hg}(\mathrm{II})]=0 / 5 \mathrm{mM}$; [buffer $]=30 \mathrm{mM} ; \mathrm{I}\left(\mathrm{NaNO}_{3}\right)=$ $100 \mathrm{mM}$.

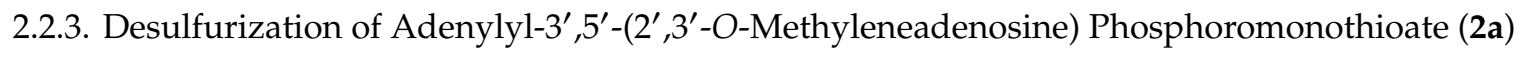

The rate of desulfurization was determined separately for both diastereomers of adenylyl- $3^{\prime}, 5^{\prime}-\left(2^{\prime}, 3^{\prime}-\mathrm{O}\right.$-methyleneadenosine) phosphoromonothioate (2a) at $0{ }^{\circ} \mathrm{C}$ and $\mathrm{pH} 6.9$ and either in the absence or at a saturating concentration of $\mathrm{Hg}$ (II). The ionic strength was adjusted to $0.10 \mathrm{M}$ with sodium nitrate. Desulfurization of $\mathbf{2 a}$ (Scheme $4, k_{4}$ ) was accompanied with apparent isomerization and cleavage of the immediate product 1a, the observed products being 1a, 1b, cAMP and $\mathbf{6}$ in a 5:4:1:1 ratio. As discussed in the literature [35], desulfurization of ribonucleoside phosphoromonothioates is initiated by nucleophilic attack of the neighboring $\mathrm{OH}$ group to give a pentacoordinate intermediate. Loss of hydrogen (or, in the presence of $\mathrm{Hg}$ (II), mercuric) sulfide from this intermediate leads to a cyclic phosphotriester that rapidly decomposes by rupture of either one of the endocyclic P-O bonds, affording $\mathbf{1 a}$ or $\mathbf{1} \mathbf{b}$, or the exocyclic P-O bond, affording cAMP and $\mathbf{6}$. This mechanism also explains the 
apparent competition between cleavage and desulfurization reported previously [17]—desulfurization always occurs first, and the competition is actually between endo- and exocyclic P-O bond fission. In the absence of $\mathrm{Hg}(\mathrm{II})$, desulfurization of both diastereomers of $2 \mathrm{a}$ proceeded at nearly equal rates $\left(k_{4}\right.$ $=7 \pm 2$ and $6 \pm 2 \times 10^{-8} \mathrm{~s}^{-1}$ for $S_{\mathrm{p}}$ and $R_{\mathrm{p}}$ diastereomers). The product distribution was unaffected by the presence of $\mathrm{Hg}(\mathrm{II})$, but the rate of desulfurization was increased by more than four orders of magnitude ( $k_{4}=4 \pm 1$ and $1.4 \pm 0.1 \times 10^{-3} \mathrm{~s}^{-1}$ for $S_{\mathrm{p}}$ and $R_{\mathrm{p}}$ diastereomers).

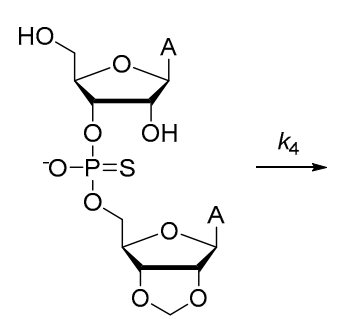

2a

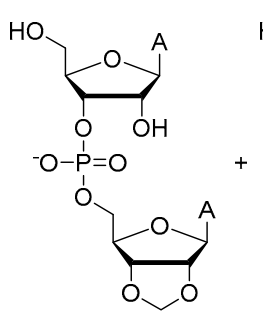

$1 \mathrm{a}$

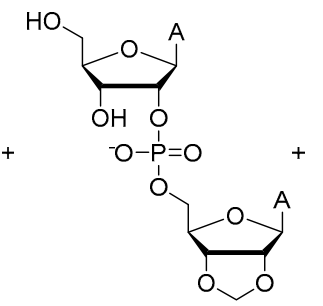

1b

Scheme 4. Desulfurization of 2a yields both cleavage and isomerization products.

\section{Materials and Methods}

\subsection{General}

Pyridine, $\mathrm{CH}_{2} \mathrm{Cl}_{2}$ and $\mathrm{MeCN}$ were dried over $4 \AA$ molecular sieves. $\mathrm{Et}_{3} \mathrm{~N}$ and $\mathrm{MeNH}_{2}$ were distilled before use. NMR spectra were recorded on a Bruker Biospin $500 \mathrm{MHz}$ NMR spectrometer (Bruker, Billerica, MA, USA), and the chemical shifts $(\delta, \mathrm{ppm})$ are quoted relative to the residual solvent peak as an internal standard. High resolution mass spectra were recorded on a Bruker Daltonics micrOTOF-Q mass spectrometer (Bruker, Billerica, MA, USA) using electrospray ionization.

\subsection{Materials}

2'-O-(tert-Butyldimethylsilyl)-5'-O-(4,4'-dimethoxytrityl)- $N^{6}$-benzoyladenosine $3^{\prime}$-(2-cyanoethyl-N,N-diisopropylphosphoramidite) was a product of Innovassynth Technologies (Khopoli, MH, India). 2'-Deoxyadenosine, $\mathrm{I}_{2}$ oxidizer solution, HEPES (free acid and sodium salt) and $\mathrm{Et}_{3} \mathrm{~N} \bullet 3 \mathrm{HF}$ were products of Sigma-Aldrich (Saint Louis, MO, USA). 5-(Benzylthio)-1H-tetrazole was a product of Glen Research (Sterling, VA, USA). $\mathrm{Et}_{3} \mathrm{~N}$ and MES monohydrate were products of Acros Organics (Geel, Belgium) and $\mathrm{MeNH}_{2}$ and $\mathrm{S}_{8}$ of Fluka (Seelze, Germany) and Merck (Darmstadt, Germany), respectively.

\subsection{Kinetic Measurements}

Reactions of $2^{\prime}$-deoxyadenosine and adenylyl- $3^{\prime}, 5^{\prime}-\left(2^{\prime}, 3^{\prime}\right.$-O-methyleneadenosine) (1a) were carried out in sealed tubes immersed in a thermostated water bath $\left(90^{\circ} \mathrm{C} \pm 0.1^{\circ} \mathrm{C}\right)$, while the desulfurization of adenylyl- $3^{\prime}, 5^{\prime}-\left(2^{\prime}, 3^{\prime}-O-\right.$-methyleneadenosine) phosphoromonothioate (2a) was carried out in an ice/water bath $\left(0{ }^{\circ} \mathrm{C}\right)$. The hydronium ion concentration of the reaction solutions was adjusted with 2-(N-morpholino)ethanesulfonic acid (MES) and $N$-(2-hydroxyethyl)piperazine- $N^{\prime}$-2-ethanesulfonic acid (HEPES) buffers. The buffer concentration used was $0.030 \mathrm{M}$. The ionic strength of the solutions was adjusted to $0.1 \mathrm{M}$ with $\mathrm{NaNO}_{3}$. $\mathrm{Hg}$ (II) ions were added as mercuric acetate. After addition of mercuric acetate, the $\mathrm{pH}$ of the reaction solutions was adjusted back to the value observed in the absence of $\mathrm{Hg}$ (II) by titrating with $1.00 \mathrm{M} \mathrm{NaOH}$.

The aliquots $(200 \mu \mathrm{L})$ withdrawn from the reaction solutions at appropriate time intervals were cooled in an ice/water bath to quench the reactions. Before analysis, $\mathrm{Hg}$ (II) was precipitated out as the tetrachloride complex by the addition of $10 \mu \mathrm{L}$ of $2.0 \mathrm{M} \mathrm{NaCl}$. Composition of the samples was determined by RP-HPLC on a Thermo Scientific Aquasil column $(4 \times 150 \mathrm{~mm}, 5 \mu \mathrm{m})$ using UV detection at $\lambda=260 \mathrm{~nm}$ and a flow rate of $1.0 \mathrm{~mL} \mathrm{~min}^{-1}$. For depurination of $2^{\prime}$-deoxyadenosine, 
isocratic elution with $6 \% \mathrm{MeCN}$ in $50 \mathrm{mM}$ aqueous $\mathrm{NH}_{4} \mathrm{OAc}$ was used, the retention times of adenine and $2^{\prime}$-deoxyadenosine being 8.1 and $12.7 \mathrm{~min}$, respectively. For the reactions of $\mathbf{1 a}$ and $\mathbf{2 a}$, the samples were eluted with linear gradients (3-15\% over $30 \mathrm{~min}$ and 3-19\% over $40 \mathrm{~min}$, respectively) of MeCN in $50 \mathrm{mM}$ aqueous $\mathrm{NH}_{4} \mathrm{OAc}$. The observed retention times (min) for the starting materials and products were 9.7 ( $2^{\prime}, 3^{\prime}$-cAMP), 14.6 (adenosine), 19.9 (1) $), 26.1$ (6), 26.8 (1a), 29.1 (2a, $S_{\mathrm{p}}$ diastereomer) and 34.5 ( $2 \mathrm{a}, R_{\mathrm{p}}$ diastereomer). The products were identified by spiking with authentic samples and by HPLC/MS analysis. Representative examples of the chromatograms of the product mixtures can be found in the Supporting Information (Figures S18-S21).

\subsection{2'-O-(tert-Butyldimethylsilyl)-5'-O-(4,4'-dimethoxytrityl)-adenylyl-3', $5^{\prime}-\left(2^{\prime}, 3^{\prime}-O-\right.$ methyleneadenosine) (4)}

$\mathrm{N}^{6}, \mathrm{~N}^{6}$-Dibenzoyl-2' ${ }^{\prime} 3^{\prime}$-O-methyleneadenosine $(200 \mathrm{mg}, 0.410 \mathrm{mmol})$ was co-evaporated three times from anhydrous pyridine, after which it was dried in a vacuum desiccator over $\mathrm{P}_{2} \mathrm{O}_{5}$ for 16 h. The dried $N^{6}, N^{6}$-dibenzoyl-2', $3^{\prime}$-O-methyleneadenosine was dissolved in anhydrous $\mathrm{MeCN}$ (3.3 $\mathrm{mL}$ ) and a solution of $2^{\prime}$-O-(tert-butyldimethylsilyl)-5'-O-(4,4'-dimethoxytrityl)- $\mathrm{N}^{6}$-benzoyladenosine $3^{\prime}$-(2-cyanoethyl- $N, N$-diisopropylphosphoramidite) $(405 \mathrm{mg}, 0.410 \mathrm{mmol})$ in anhydrous $\mathrm{MeCN}$ (3.3 $\mathrm{mL}$ ) was added, followed by a solution of 5-(benzylthio)- $1 \mathrm{H}$-tetrazole $(0.82 \mathrm{mmol})$ in anhydrous $\mathrm{MeCN}$ ( $3.3 \mathrm{~mL}$ ). The reaction mixture was stirred at $25^{\circ} \mathrm{C}$ under $\mathrm{N}_{2}$ for $15 \mathrm{~min}$, after which it was divided into two equal portions for the synthesis of compounds 4 and 5 .

For the synthesis of compound 4 , a solution of $\mathrm{I}_{2}(0.24 \mathrm{mmol})$ in a mixture of THF $(6.9 \mathrm{~mL}), \mathrm{H}_{2} \mathrm{O}$ $(3.4 \mathrm{~mL})$ and pyridine $(1.7 \mathrm{~mL})$ was added. After stirring at $25^{\circ} \mathrm{C}$ for $5 \mathrm{~min}$, the reaction was quenched by addition of $5 \%$ aqueous $\mathrm{NaHSO}_{3}(100 \mathrm{~mL})$. Phases were separated, the aqueous phase was extracted with $\mathrm{CH}_{2} \mathrm{Cl}_{2}(2 \times 100 \mathrm{~mL})$, the combined organic phases were dried on $\mathrm{Na}_{2} \mathrm{SO}_{4}$ and evaporated to dryness. The residue was dissolved in a mixture of pyridine $(15 \mathrm{~mL})$ and $\mathrm{Et}_{3} \mathrm{~N}(5 \mathrm{~mL})$ and the resulting solution was stirred $25^{\circ} \mathrm{C}$ for $16 \mathrm{~h}$, after which it was evaporated to dryness. The crude phosphodiester intermediate thus obtained was dissolved in a mixture of $33 \%$ aqueous $\mathrm{NH}_{3}(3 \mathrm{~mL})$ and $40 \%$ aqueous $\mathrm{MeNH}_{2}(3 \mathrm{~mL})$. After being stirred at $25^{\circ} \mathrm{C}$ for $1 \mathrm{~h}$, the solution was evaporated to dryness and the residue purified on a silica gel column eluting with a mixture of $\mathrm{CH}_{2} \mathrm{Cl}_{2}, \mathrm{MeOH}$ and $\mathrm{Et}_{3} \mathrm{~N}$ (94:5:1, $v / v)$. Compound 4 was obtained as a solid triethylammonium salt in $25 \%$ yield $(58.0 \mathrm{mg}) .{ }^{1} \mathrm{H}$ NMR $\left(500 \mathrm{MHz}, \mathrm{CDCl}_{3}\right) \delta: 8.39$ (s, 1H, H8), 8.32 (s, 1H, H2), $8.22(\mathrm{~s}, 1 \mathrm{H}, \mathrm{H} 2), 8.06$ (s, 1H, H8), 7.46 (m, 2H, DMTr), 7.35 (m, 4H, DMTr), 7.27-7.18 (m, 3H, DMTr), 6.80 (m, 4H, DMTr), 6.30 (br, 2H, NH $), 6.20$ (d, $\left.J=3.0 \mathrm{~Hz}, 1 \mathrm{H}, \mathrm{H1}^{\prime}\right), 6.13\left(\mathrm{~d}, J=5.5 \mathrm{~Hz}, 1 \mathrm{H}, \mathrm{H} 1^{\prime}\right), 6.01\left(\mathrm{br}, 2 \mathrm{H}, \mathrm{NH}_{2}\right), 5.23\left(\mathrm{~s}, 1 \mathrm{H}, \mathrm{OCH}_{2} \mathrm{O}\right), 5.16(\mathrm{dd}$, $\left.J=6.0,3.0 \mathrm{~Hz}, 1 \mathrm{H}, \mathrm{H} 2^{\prime}\right), 5.06\left(\mathrm{~s}, 1 \mathrm{H}, \mathrm{OCH}_{2} \mathrm{O}\right), 5.00\left(\mathrm{~m}, 1 \mathrm{H}, \mathrm{H} 2^{\prime}\right), 5.04\left(\mathrm{dd}, J=6.5,2.5 \mathrm{~Hz}, 1 \mathrm{H}, \mathrm{H}^{\prime}\right)^{\prime}$, $4.78\left(\mathrm{~m}, 1 \mathrm{H}, \mathrm{H} 3^{\prime}\right), 4.59\left(\mathrm{~m}, 1 \mathrm{H}, \mathrm{H} 4^{\prime}\right), 4.40\left(\mathrm{~m}, 1 \mathrm{H}, \mathrm{H} 4^{\prime}\right), 4.02\left(\mathrm{~m}, 1 \mathrm{H}, \mathrm{H} 5^{\prime}\right), 3.97\left(\mathrm{~m}, 1 \mathrm{H}, \mathrm{H} 5^{\prime}\right), 3.756(\mathrm{~s}$, $\left.3 \mathrm{H}, \mathrm{OCH}_{3}\right), 3.755\left(\mathrm{~s}, 3 \mathrm{H}, \mathrm{OCH}_{3}\right), 3.55\left(\mathrm{dd}, J=10.5,3.0 \mathrm{~Hz}, 1 \mathrm{H}, \mathrm{H} 5^{\prime}\right), 3.46\left(\mathrm{~m}, 1 \mathrm{H}, \mathrm{H} 5^{\prime \prime}\right), 0.77(\mathrm{~s}, 9 \mathrm{H}$, $\left.\mathrm{SiC}\left(\mathrm{CH}_{3}\right)_{3}\right), 0.04\left(\mathrm{~s}, 3 \mathrm{H}, \mathrm{SiCH}_{3}\right),-0.08\left(\mathrm{~s}, 3 \mathrm{H}, \mathrm{SiCH}_{3}\right) .{ }^{13} \mathrm{C} \mathrm{NMR}\left(126 \mathrm{MHz}, \mathrm{CDCl}_{3}\right) \delta: 158.5(\mathrm{DMTr})$, 155.6 (C6), 155.4 (C6), 153.2 (C2), 152.9 (C2), 150.1 (C4), 149.7 (C4), 144.6 (DMTr), 139.7 (C8), 139.1 (C8), 135.7 (DMTr), 130.2 (DMTr), 128.3 (DMTr), 127.9 (DMTr), 126.9 (DMTr), 119.9 (C5), 119.4 (C5), 113.2 (DMTr), $96.4\left(\mathrm{OCH}_{2} \mathrm{O}\right), 89.3,\left(\mathrm{Cl}^{\prime}\right), 87.9\left(\mathrm{Cl}^{\prime}\right), 86.6(\mathrm{DMTr}), 84.4\left(\mathrm{~d}, J=7.2 \mathrm{~Hz}, \mathrm{C} 4^{\prime}\right), 84.2\left(\mathrm{C}^{\prime}\right), 83.2(\mathrm{~d}, J$ $\left.=7.2 \mathrm{~Hz}, \mathrm{C}^{\prime}\right), 81.6\left(\mathrm{C}^{\prime}\right), 75.2\left(\mathrm{~d}, J=5.3 \mathrm{~Hz}, \mathrm{C} 2^{\prime}\right), 74.7\left(\mathrm{~d}, J=5.3 \mathrm{~Hz}, \mathrm{C} 3^{\prime}\right), 65.6\left(\mathrm{~d}, J=5.0 \mathrm{~Hz}, \mathrm{C} 5^{\prime}\right), 63.7$ $\left(\mathrm{C}^{\prime}\right), 55.2\left(\mathrm{OCH}_{3}\right), 25.6\left(\mathrm{SiC}\left(\mathrm{CH}_{3}\right)_{3}\right), 18.3\left(\mathrm{SiC}\left(\mathrm{CH}_{3}\right)_{3}\right),-4.8\left(\mathrm{SiCH}_{3}\right),-5.2\left(\mathrm{SiCH}_{3}\right) .{ }^{31} \mathrm{P} \mathrm{NMR}(202 \mathrm{MHz}$, $\mathrm{CDCl}_{3}$ ): $\delta=-1.6$. HRMS (ESI) $m / z$ : $[\mathrm{M}-\mathrm{H}]^{-}$calcd for $\mathrm{C}_{48} \mathrm{H}_{56} \mathrm{~N}_{10} \mathrm{O}_{12} \mathrm{Psi}^{-} 1023.3592$, found 1023.3625.

3.5. 2'-O-(tert-Butyldimethylsilyl)-5'-O-(4,4'-dimethoxytrityl)-adenylyl-3', $5^{\prime}-\left(2^{\prime}, 3^{\prime}-O-m e t h y l e n e a d e n o s i n e\right)$ phosphoromonothioate (5)

For the synthesis of compound 5, $\mathrm{S}_{8}(20 \mathrm{mg}, 0.62 \mathrm{mmol})$ and $\mathrm{CH}_{2} \mathrm{Cl}_{2}(5.0 \mathrm{~mL})$ were added to the other half of the $\mathrm{MeCN}$ solution containing the crude phosphite triester (approximately 0.205 mmol) prepared above. The resulting mixture was stirred at $25^{\circ} \mathrm{C}$ for $16 \mathrm{~h}$, after which $\mathrm{H}_{2} \mathrm{O}(100 \mathrm{~mL})$ and $\mathrm{CH}_{2} \mathrm{Cl}_{2}(100 \mathrm{~mL})$ were added. Phases were separated and the organic phase dried on $\mathrm{Na}_{2} \mathrm{SO}_{4}$ and evaporated to dryness. The residue was dissolved in a mixture of pyridine $(15 \mathrm{~mL})$ and $\mathrm{Et}_{3} \mathrm{~N}$ 
$(5 \mathrm{~mL})$ and the resulting solution was stirred $25{ }^{\circ} \mathrm{C}$ for $16 \mathrm{~h}$, after which it was evaporated to dryness. The crude phosphorothioate diester intermediate, thus, obtained was dissolved in a mixture of $33 \%$ aqueous $\mathrm{NH}_{3}(3 \mathrm{~mL})$ and $40 \%$ aqueous $\mathrm{MeNH}_{2}(3 \mathrm{~mL})$. After being stirred at $25^{\circ} \mathrm{C}$ for $1 \mathrm{~h}$, the solution was evaporated to dryness and the residue purified on a silica gel column eluting with a mixture of $\mathrm{CH}_{2} \mathrm{Cl}_{2}, \mathrm{MeOH}$ and $\mathrm{Et}_{3} \mathrm{~N}(97: 2: 1, v / v)$. Compound 5 was obtained as a solid triethylammonium salt in $27 \%$ yield $\left(65.0 \mathrm{mg}\right.$, mixture of two diastereomers in approximately $2: 3$ ratio). ${ }^{1} \mathrm{H}$ NMR $(500 \mathrm{MHz}$, $\mathrm{CDCl}_{3}$, major diastereomer) $\delta: 8.42(\mathrm{~s}, 1 \mathrm{H}, \mathrm{H} 8), 8.31(\mathrm{~s}, 1 \mathrm{H}, \mathrm{H} 2), 8.18(\mathrm{~s}, 1 \mathrm{H}, \mathrm{H} 2), 8.04(\mathrm{~s}, 1 \mathrm{H}, \mathrm{H} 8), 7.47$ (m, 2H, DMTr), $7.36(\mathrm{~m}, 4 \mathrm{H}, \mathrm{DMTr}), 7.26(\mathrm{~m}, 2 \mathrm{H}, \mathrm{DMTr}), 7.18(\mathrm{~m}, 1 \mathrm{H}, \mathrm{DMTr}), 6.80(\mathrm{~d}, J=8.5 \mathrm{~Hz}, 4 \mathrm{H}$, DMTr), $6.46\left(\mathrm{br}, 2 \mathrm{H}, \mathrm{NH}_{2}\right), 6.28\left(\mathrm{br}, 2 \mathrm{H}, \mathrm{NH}_{2}\right), 6.21\left(\mathrm{~d}, J=3.0 \mathrm{~Hz}, 1 \mathrm{H}, \mathrm{H}^{\prime}\right), 6.14(\mathrm{~d}, J=6.5 \mathrm{~Hz}, 1 \mathrm{H}$, $\left.\mathrm{H} 1^{\prime}\right), 5.25\left(\mathrm{~s}, 1 \mathrm{H}, \mathrm{OCH}_{2} \mathrm{O}\right), 5.22\left(\mathrm{dd}, J=6.5,3.0 \mathrm{~Hz}, 1 \mathrm{H}, \mathrm{H} 2^{\prime}\right), 5.12\left(\mathrm{~s}, 1 \mathrm{H}, \mathrm{OCH}_{2} \mathrm{O}\right), 5.11-5.06(\mathrm{~m}, 2 \mathrm{H}$, $\left.2 \times \mathrm{H}^{\prime}\right), 4.97\left(\mathrm{dd}, J=6.0,2.5 \mathrm{~Hz}, 1 \mathrm{H}, \mathrm{H}^{\prime}\right), 4.70\left(\mathrm{~m}, 1 \mathrm{H}, \mathrm{H} 4^{\prime}\right), 4.52\left(\mathrm{~m}, 1 \mathrm{H}, \mathrm{H} 4^{\prime}\right), 4.20\left(\mathrm{~m}, 2 \mathrm{H}, \mathrm{H}^{\prime}\right.$ \& $\left.\left.\mathrm{H}^{\prime \prime}{ }^{\prime \prime}\right), 3.75\left(\mathrm{~s}, 3 \mathrm{H}, \mathrm{OCH}_{3}\right), 3.74\left(\mathrm{~s}, 3 \mathrm{H}, \mathrm{OCH}_{3}\right), 3.52-3.40\left(\mathrm{~m}, 2 \mathrm{H}, \mathrm{H} 5^{\prime} \& \mathrm{H}^{\prime \prime}\right)^{\prime}\right), 0.68\left(\mathrm{~s}, \mathrm{SiC}\left(\mathrm{CH}_{3}\right)_{3}\right),-0.06$ $\left(\mathrm{s}, 3 \mathrm{H}, \mathrm{SiCH}_{3}\right),-0.20\left(\mathrm{~s}, 3 \mathrm{H}, \mathrm{SiCH}_{3}\right) .{ }^{1} \mathrm{H}$ NMR $\left(500 \mathrm{MHz} \mathrm{CDCl}_{3}\right.$, minor diastereomer) $\delta: 8.38(\mathrm{~s}, 1 \mathrm{H}$, $\mathrm{H} 8), 8.28$ (s, 1H, H2), 8.23 (s, 1H, H2), 8.05 (s, 1H, H8), 7.47 (m, 2H, DMTr), 7.36 (m, 4H, DMTr), 7.26 (m, 2H, DMTr), $7.18(\mathrm{~m}, 1 \mathrm{H}, \mathrm{DMTr}), 6.33\left(\mathrm{br}, 2 \mathrm{H}, \mathrm{NH}_{2}\right), 6.16\left(\mathrm{~d}, J=2.5 \mathrm{~Hz}, 1 \mathrm{H}, \mathrm{H} 1^{\prime}\right), 6.10(\mathrm{~d}, J=6.0$ $\left.\mathrm{Hz}, 1 \mathrm{H}, \mathrm{H1}^{\prime}\right), 5.99\left(\mathrm{br}, 2 \mathrm{H}, \mathrm{NH}_{2}\right), 5.17\left(\mathrm{~s}, 1 \mathrm{H}, \mathrm{OCH}_{2} \mathrm{O}\right), 5.13\left(\mathrm{~m}, 1 \mathrm{H}, \mathrm{H}^{\prime}\right), 5.11-5.06\left(\mathrm{~m}, 3 \mathrm{H}, \mathrm{H} 2^{\prime}\right.$ \& $2 \times$ $\left.\mathrm{H} 3^{\prime}\right), 5.01\left(\mathrm{~s}, 1 \mathrm{H}, \mathrm{OCH}_{2} \mathrm{O}\right), 4.52\left(\mathrm{~m}, 1 \mathrm{H}, \mathrm{H} 4^{\prime}\right), 4.36\left(\mathrm{~m}, 1 \mathrm{H}, \mathrm{H} 4^{\prime}\right), 4.07\left(\mathrm{~m}, 1 \mathrm{H}, \mathrm{H} 5^{\prime}\right), 3.99\left(\mathrm{~m}, 1 \mathrm{H}, \mathrm{H} 5^{\prime \prime}\right)$, $3.75\left(\mathrm{~s}, 3 \mathrm{H}, \mathrm{OCH}_{3}\right), 3.74\left(\mathrm{~s}, 3 \mathrm{H}, \mathrm{OCH}_{3}\right), 3.52-3.40\left(\mathrm{~m}, 2 \mathrm{H}, \mathrm{H} 5^{\prime} \& \mathrm{H}^{\prime \prime}\right), 0.71\left(\mathrm{~s}, \mathrm{SiC}\left(\mathrm{CH}_{3}\right)_{3}\right), 0.03(\mathrm{~s}, 3 \mathrm{H}$, $\left.\mathrm{SiCH}_{3}\right),-0.11\left(\mathrm{~s}, 3 \mathrm{H}, \mathrm{SiCH}_{3}\right) .{ }^{13} \mathrm{C} \mathrm{NMR}\left(126 \mathrm{MHz}_{2} \mathrm{CDCl}_{3}\right.$, major diastereomer) $\delta: 158.5$ (DMTr), 155.6 (C6), 155.5 (C6), 153.0 (C2), 152.7 (C2), 150.1 (C4), 149.6 (C4), 144.7 (DMTr), 139.7 (C8), 139.4 (C8), 135.8 (DMTr), 130.2 (DMTr), 128.3 (DMTr), 127.9 (DMTr), 126.5 (DMTr), 119.8 (C5), 119.6 (C5), 113.3 (DMTr), $96.4\left(\mathrm{OCH}_{2} \mathrm{O}\right), 89.9\left(\mathrm{C1}^{\prime}\right), 87.5\left(\mathrm{C1}^{\prime}\right), 86.7(\mathrm{DMTr}), 84.5\left(\mathrm{~d}, J=9.1 \mathrm{~Hz}, \mathrm{C} 4^{\prime}\right), 84.3\left(\mathrm{C}^{\prime}\right), 83.7\left(\mathrm{C}^{\prime}\right), 82.0$ $\left(\mathrm{C}^{\prime}\right), 75.7\left(\mathrm{~d}, J=5.2 \mathrm{~Hz}, \mathrm{C} 2^{\prime}\right), 75.1\left(\mathrm{~d}, J=8.7 \mathrm{~Hz}, \mathrm{C} 3^{\prime}\right), 66.2\left(\mathrm{~d}, J=5.6 \mathrm{~Hz}, \mathrm{C}^{\prime}\right), 64.0\left(\mathrm{C}^{\prime}\right), 55.2\left(\mathrm{OCH}_{3}\right)$, $25.5\left(\mathrm{SiC}\left(\underline{\mathrm{CH}}_{3}\right)_{3}\right), 17.9\left(\mathrm{SiC}\left(\mathrm{CH}_{3}\right)_{3}\right),-4.8\left(\mathrm{SiCH}_{3}\right),-5.4\left(\mathrm{SiCH}_{3}\right) .{ }^{13} \mathrm{C} \mathrm{NMR}\left(126 \mathrm{MHz}, \mathrm{CDCl}_{3}\right.$, minor diastereomer) $\delta$ : 158.5 (DMTr), 155.6 (C6), 155.4 (C6), 153.0 (C2), 152.7 (C2), 150.0 (C4), 149.5 (C4), 144.6 (DMTr), 139.6 (C8), 139.0 (C8), 135.7 (DMTr), 130.2 (DMTr), 128.3 (DMTr), 127.9 (DMTr), 126.5 (DMTr), 119.7 (C5), 119.4 (C5), 113.2 (DMTr), 96.3 ( $\left.\mathrm{OCH}_{2} \mathrm{O}\right), 89.4\left(\mathrm{C1}^{\prime}\right), 87.6\left(\mathrm{C1}^{\prime}\right), 86.7$ (DMTr), 84.4 (C4'), 84.1 $\left(\mathrm{C} 2^{\prime}\right), 83.1\left(\mathrm{C}^{\prime}\right), 81.7\left(\mathrm{C}^{\prime}\right), 75.2\left(\mathrm{~d}, J=7.6 \mathrm{~Hz}, \mathrm{C} 2^{\prime}\right), 75.4\left(\mathrm{~d}, J=6.9 \mathrm{~Hz}, \mathrm{C} 3^{\prime}\right), 65.6\left(\mathrm{~d}, J=5.6 \mathrm{~Hz}, \mathrm{C}^{\prime}\right)$, $63.8\left(\mathrm{C}^{\prime}\right), 55.2\left(\mathrm{OCH}_{3}\right), 25.6\left(\mathrm{SiC}\left(\mathrm{CH}_{3}\right)_{3}\right), 18.0\left(\mathrm{SiC}\left(\mathrm{CH}_{3}\right)_{3}\right),-4.6\left(\mathrm{SiCH}_{3}\right),-5.3\left(\mathrm{SiCH}_{3}\right) .{ }^{31} \mathrm{P} \mathrm{NMR}(202$ $\mathrm{MHz}, \mathrm{CDCl}_{3}$, major diastereomer): $\delta: 57.8 .{ }^{31} \mathrm{P} \mathrm{NMR}\left(202 \mathrm{MHz}, \mathrm{CDCl}_{3}\right.$, minor diastereomer): $\delta: 58.3$. HRMS (ESI) $m / z$ : [M - H] $]^{-}$calcd for $1039.3363 \mathrm{C}_{48} \mathrm{H}_{56} \mathrm{~N}_{10} \mathrm{O}_{11} \mathrm{PSSi}^{-}$, found 1039.3397.

\subsection{Adenylyl-3', $5^{\prime}-\left(2^{\prime}, 3^{\prime}-O-m e t h y l e n e a d e n o s i n e\right)(1 \mathbf{a})$}

Compound 4 ( $37.0 \mathrm{mg}, 0.0361 \mathrm{mmol})$ and triethylamine trihydrofluoride $(44.0 \mu \mathrm{L}, 0.270 \mathrm{mmol})$ were dissolved in anhydrous $\mathrm{CH}_{2} \mathrm{Cl}_{2}(2.0 \mathrm{~mL})$. After stirring for $72 \mathrm{~h}$, the precipitation formed was recovered and washed with $\mathrm{CH}_{2} \mathrm{Cl}_{2}(3 \times 5 \mathrm{~mL})$. The crude product was purified by reverse phase chromatography on a ThermoHypersil Hyperprep column $(10 \times 250 \mathrm{~mm}, 8 \mu \mathrm{m})$ eluting with a mixture of $\mathrm{MeCN}$ and $50 \mathrm{mM}$ aqueous ammonium formate $(11: 89, v / v)$. Compound 1a was obtained as a solid ammonium salt in $31 \%$ yield $(6.8 \mathrm{mg}) .{ }^{1} \mathrm{H}$ NMR $\left(500 \mathrm{MHz}, \mathrm{D}_{2} \mathrm{O}\right) \delta: 8.25(\mathrm{~s}, 1 \mathrm{H}, \mathrm{H} 8), 8.17(\mathrm{~s}, 1 \mathrm{H}, \mathrm{H} 8)$, $8.09(\mathrm{~s}, 1 \mathrm{H}, \mathrm{H} 2), 8.05(\mathrm{~s}, 1 \mathrm{H}, \mathrm{H} 2), 6.14\left(\mathrm{~d}, J=3.0 \mathrm{~Hz}, 1 \mathrm{H}, \mathrm{H} 1^{\prime}\right), 5.75\left(\mathrm{~d}, J=5.0 \mathrm{~Hz}, 1 \mathrm{H}, \mathrm{H} 1^{\prime}\right), 5.22(\mathrm{dd}, J=$ 6.5, 3.0 Hz, 1H, H2'), $5.20\left(\mathrm{~s}, 1 \mathrm{H}, \mathrm{OCH}_{2} \mathrm{O}\right), 5.17\left(\mathrm{~s}, 1 \mathrm{H}, \mathrm{OCH}_{2} \mathrm{O}\right), 5.04\left(\mathrm{dd}, J=6.5,4.0 \mathrm{~Hz}, 1 \mathrm{H}, \mathrm{H}^{\prime}\right)$, 4.56-4.52 (m, 3H, H2' $\left.{ }^{\prime} \mathrm{H}^{\prime} \& \mathrm{H} 4^{\prime}\right), 4.20\left(\mathrm{dt}, J=11.5,3.0 \mathrm{~Hz}, 1 \mathrm{H}, \mathrm{H} 5^{\prime}\right), 4.15-4.12\left(\mathrm{~m}, 2 \mathrm{H}, \mathrm{H} 4^{\prime}, \mathrm{H}^{\prime \prime}\right), 3.65$ $\left(\mathrm{d}, J=3.0,2 \mathrm{H}, \mathrm{H}^{\prime}, \mathrm{H}^{\prime \prime}\right) .{ }^{13} \mathrm{C}$ NMR $\left(126 \mathrm{MHz}, \mathrm{D}_{2} \mathrm{O}\right) \delta: 154.8(\mathrm{C} 6), 154.5$ (C6), $151.5(\mathrm{C} 2), 151.4(\mathrm{C} 2)$, 148.3 (C4), $148.0(\mathrm{C} 4), 140.7$ (C8), $140.4(\mathrm{C} 8), 119.1(\mathrm{C} 5), 118.5(\mathrm{C} 5), 95.7\left(\mathrm{OCH}_{2} \mathrm{O}\right), 88.7\left(\mathrm{Cl}^{\prime}\right), 88.6\left(\mathrm{Cl}^{\prime}\right)$, $84.2\left(\mathrm{~d}, J=3.9 \mathrm{~Hz}, \mathrm{C} 4^{\prime}\right), 83.4\left(\mathrm{~d}, J=9.2 \mathrm{~Hz}, \mathrm{C} 4^{\prime}\right), 83.2\left(\mathrm{C2}^{\prime}\right), 80.1\left(\mathrm{C}^{\prime}\right), 74.4\left(\mathrm{~d}, J=5.5 \mathrm{~Hz}, \mathrm{C} 3^{\prime}\right), 73.1(\mathrm{~d}, J$ $\left.=5.5 \mathrm{~Hz}, \mathrm{C} 2^{\prime}\right), 65.7\left(\mathrm{~d}, J=5.6 \mathrm{~Hz}, \mathrm{C} 5^{\prime}\right), 60.9\left(\mathrm{C}^{\prime}\right) .{ }^{31} \mathrm{P}$ NMR $\left(202 \mathrm{MHz}, \mathrm{D}_{2} \mathrm{O}\right): \delta=-0.93$. HRMS (ESI) $m / z:[\mathrm{M}-\mathrm{H}]^{-}$calcd for $\mathrm{C}_{21} \mathrm{H}_{23} \mathrm{~N}_{10} \mathrm{O}_{10} \mathrm{P}^{-}$607.1420; found 607.1424. 


\subsection{Adenylyl-3', $5^{\prime}-\left(2^{\prime}, 3^{\prime}-\right.$ O-methyleneadenosine) phosphoromonothioate (2a)}

Compound $5(70 \mathrm{mg}, 0,068 \mathrm{mmol})$ and triethylamine trihydrofluoride $(44.0 \mu \mathrm{L}, 0.270 \mathrm{mmol})$ were dissolved in anhydrous $\mathrm{CH}_{2} \mathrm{Cl}_{2}(2.0 \mathrm{~mL})$. After stirring for $72 \mathrm{~h}$, the precipitation formed was recovered and washed with $\mathrm{CH}_{2} \mathrm{Cl}_{2}(3 \times 5 \mathrm{~mL})$. The crude product was purified by reverse phase chromatography on a ThermoHypersil Hyperprep column $(10 \times 250 \mathrm{~mm}, 8 \mu \mathrm{m})$ eluting with a mixture of MeCN and 50 $\mathrm{mM}$ aqueous ammonium formate $(15: 85, v / v)$. Compound $\mathbf{2 a}$ was obtained as a solid ammonium salt in a $27 \%$ overall yield ( 6.5 and $4.5 \mathrm{mg}$ of the faster and slower eluting diastereomers, respectively). The faster and slower eluting diastereomers were assigned as the $S_{\mathrm{p}}$ and $R_{\mathrm{p}}$ diastereomers based on their ${ }^{31} \mathrm{P}$ chemical shifts, as described in the literature [20]. ${ }^{1} \mathrm{H}$ NMR $\left(500 \mathrm{MHz},\left(\mathrm{CD}_{3}\right)_{2} \mathrm{SO}, R_{\mathrm{p}}\right.$ diastereomer $)$ $\delta: 8.53(\mathrm{~s}, 1 \mathrm{H}, \mathrm{H} 8), 8.45(\mathrm{~s}, 1 \mathrm{H}, \mathrm{H} 8), 8.26(\mathrm{~s}, 1 \mathrm{H}, \mathrm{H} 2), 8.22(\mathrm{~s}, 1 \mathrm{H}, \mathrm{H} 2), 7.81\left(\mathrm{br}, 4 \mathrm{H}, \mathrm{NH}_{2}\right), 6.20(\mathrm{~d}, J=3.0$ $\left.\mathrm{Hz}, 1 \mathrm{H}, \mathrm{H} 1^{\prime}\right), 5.91\left(\mathrm{~d}, J=7.0 \mathrm{~Hz}, 1 \mathrm{H}, \mathrm{H} 1^{\prime}\right), 5.31\left(\mathrm{dd}, J=6.5,3.0 \mathrm{~Hz}, 1 \mathrm{H}, \mathrm{H} 2^{\prime}\right), 5.19\left(\mathrm{~s}, 1 \mathrm{H}, \mathrm{OCH}_{2} \mathrm{O}\right), 5.15$ $\left(\mathrm{s}, 1 \mathrm{H}, \mathrm{OCH}_{2} \mathrm{O}\right), 5.03\left(\mathrm{dd}, J=6.5,3.0 \mathrm{~Hz}, 1 \mathrm{H}, \mathrm{H}^{\prime}\right), 4.83\left(\mathrm{~m}, 1 \mathrm{H}, \mathrm{H}^{\prime}\right), 4.70\left(\mathrm{~m}, 1 \mathrm{H}, \mathrm{H} 2^{\prime}\right), 4.41(\mathrm{~m}, 1 \mathrm{H}$, $\left.\mathrm{H} 4^{\prime}\right), 4.14\left(\mathrm{~m}, 1 \mathrm{H}, \mathrm{H} 4^{\prime}\right), 4.07\left(\mathrm{~m}, 1 \mathrm{H}, \mathrm{H} 5^{\prime}\right), 4.02\left(\mathrm{~m}, 1 \mathrm{H}, \mathrm{H}^{\prime \prime}\right), 3.65\left(\mathrm{dd}, J=12.5,3.0 \mathrm{~Hz}, 1 \mathrm{H}, \mathrm{H} 5^{\prime}\right), 3.56$ $\left(\mathrm{dd}, J=12.5,3.0 \mathrm{~Hz}, 1 \mathrm{H}, \mathrm{H}^{\prime \prime}\right) .{ }^{1} \mathrm{H}$ NMR $\left(500 \mathrm{MHz},\left(\mathrm{CD}_{3}\right)_{2} \mathrm{SO}, S_{\mathrm{p}}\right.$ diastereomer $) \delta: 8.55(\mathrm{~s}, 1 \mathrm{H}, \mathrm{H} 8), 8.43$ $(\mathrm{s}, 1 \mathrm{H}, \mathrm{H} 8), 8.26(\mathrm{~s}, 1 \mathrm{H}, \mathrm{H} 2), 8.21(\mathrm{~s}, 1 \mathrm{H}, \mathrm{H} 2), 7.78\left(\mathrm{br}, 4 \mathrm{H}, \mathrm{NH}_{2}\right), 6.19\left(\mathrm{~d}, J=3.0 \mathrm{~Hz}, 1 \mathrm{H}, \mathrm{H} 1^{\prime}\right), 5.91(\mathrm{~d}, J=$ $\left.6.5 \mathrm{~Hz}, 1 \mathrm{H}, \mathrm{H}^{\prime}\right), 5.29\left(\mathrm{dd}, J=6.3,3.0 \mathrm{~Hz}, 1 \mathrm{H}, \mathrm{H} 2^{\prime}\right), 5.19\left(\mathrm{~s}, 1 \mathrm{H}, \mathrm{OCH}_{2} \mathrm{O}\right), 5.14\left(\mathrm{~s}, 1 \mathrm{H}, \mathrm{OCH}_{2} \mathrm{O}\right), 5.02(\mathrm{dd}$, $\left.J=6.3,3.3 \mathrm{~Hz}, 1 \mathrm{H}, \mathrm{H} 3^{\prime}\right), 4.74-4.70\left(\mathrm{~m}, 2 \mathrm{H}, \mathrm{H} 2^{\prime} \& \mathrm{H} 3^{\prime}\right), 4.41\left(\mathrm{~m}, 1 \mathrm{H}, \mathrm{H} 4^{\prime}\right), 4.15\left(\mathrm{~m}, 1 \mathrm{H}, \mathrm{H} 4^{\prime}\right), 4.07(\mathrm{~m}, 1 \mathrm{H}$, $\left.\mathrm{H}^{\prime}\right), 3.99\left(\mathrm{~m}, 1 \mathrm{H}, \mathrm{H}^{\prime \prime}\right), 3.60\left(\mathrm{dd}, J=12.0,3.0 \mathrm{~Hz}, 3.51\left(\mathrm{dd}, J=12.0,3.0 \mathrm{~Hz}, 1 \mathrm{H}, \mathrm{H} 5^{\prime \prime}\right) .{ }^{13} \mathrm{C} \mathrm{NMR}(126\right.$ $\mathrm{MHz},\left(\mathrm{CD}_{3}\right)_{2} \mathrm{SO}, R_{\mathrm{p}}$ diastereomer) $\delta$ : $155.4(\mathrm{C} 6), 155.2(\mathrm{C} 6), 151.5(\mathrm{C} 2), 151.3(\mathrm{C} 2), 149.31(\mathrm{C} 4), 149.26$ (C4), 140.8 (C8), 140.7 (C8), $119.7(\mathrm{C} 5), 119.3(\mathrm{C} 5), 95.7\left(\mathrm{OCH}_{2} \mathrm{O}\right), 88.6\left(\mathrm{C1}^{\prime}\right), 88.4\left(\mathrm{C1}^{\prime}\right), 85.4(\mathrm{~d}, J=6.8$ $\left.\mathrm{Hz}, \mathrm{C} 4^{\prime}\right), 83.6\left(\mathrm{~d}, J=8.1 \mathrm{~Hz}, \mathrm{C} 4^{\prime}\right), 83.2\left(\mathrm{C2}^{\prime}\right), 81.4\left(\mathrm{C}^{\prime}\right), 75.2\left(\mathrm{~d}, J=8.1 \mathrm{~Hz}, \mathrm{C} 3^{\prime}\right), 73.6\left(\mathrm{C}^{\prime}\right), 65.8(\mathrm{~d}, J$ $\left.=5.5 \mathrm{~Hz}, \mathrm{C}^{\prime}\right), 61.9\left(\mathrm{C}^{\prime}\right) .{ }^{13} \mathrm{C} \mathrm{NMR}\left(126 \mathrm{MHz},\left(\mathrm{CD}_{3}\right)_{2} \mathrm{SO}, S_{\mathrm{p}}\right.$ diastereomer $) \delta: 155.4(\mathrm{C} 6), 155.1(\mathrm{C} 6)$, 151.5 (C2), 151.3 (C2), 149.33 (C4), 149.26 (C4), 140.8 (2× C8), 119.7 (C5), 119.2 (C5), $95.7\left(\mathrm{OCH}_{2} \mathrm{O}\right), 88.5$ $\left(\mathrm{C1}^{\prime}\right), 88.3\left(\mathrm{C1}^{\prime}\right), 85.7\left(\mathrm{~d}, J=4.5 \mathrm{~Hz}, \mathrm{C} 4^{\prime}\right), 83.5\left(\mathrm{~d}, J=8.7 \mathrm{~Hz}, \mathrm{C} 4^{\prime}\right), 83.3\left(\mathrm{C2}^{\prime}\right), 81.4\left(\mathrm{C}^{\prime}\right), 75.8(\mathrm{~d}, J=5.9$ $\left.\mathrm{Hz}, \mathrm{C}^{\prime}\right), 73.3\left(\mathrm{~d}, J=3.3 \mathrm{~Hz}, \mathrm{C2} 2^{\prime}\right), 65.8\left(\mathrm{~d}, J=5.6 \mathrm{~Hz}, \mathrm{C} 5^{\prime}\right), 62.0\left(\mathrm{C}^{\prime}\right) .{ }^{31} \mathrm{P} \mathrm{NMR}\left(202 \mathrm{MHz},\left(\mathrm{CD}_{3}\right)_{2} \mathrm{SO}\right.$, $R_{\mathrm{p}}$ diastereomer): $\delta=58.7 .{ }^{31} \mathrm{P} \mathrm{NMR}\left(202 \mathrm{MHz},\left(\mathrm{CD}_{3}\right)_{2} \mathrm{SO}, S_{\mathrm{p}}\right.$ diastereomer): $\delta=57.2$. HRMS (ESI) $\mathrm{m} / z$ : $[\mathrm{M}-\mathrm{H}]^{-}$calcd for $\mathrm{C}_{21} \mathrm{H}_{23} \mathrm{~N}_{10} \mathrm{O}_{9} \mathrm{PS}^{-}$623.1192, found 623.1221.

\section{8. $N^{6}, N^{6}$-dibenzoyl-2', $3^{\prime}$-O-methyleneadenosine (3)}

Compound 3 was prepared from $2^{\prime}, 3^{\prime}$-O-methyleneadenosine [36] as described previously for $N^{6}, N^{6}$-dibenzoyladenosine [37]. ${ }^{1} \mathrm{H}$ NMR $\left(500 \mathrm{MHz}, \mathrm{CDCl}_{3}\right) \delta: 8.76(\mathrm{~s}, 1 \mathrm{H}, \mathrm{H} 2), 8.21(\mathrm{~s}, 1 \mathrm{H}, \mathrm{H} 8), 8.09$ (m, 2H, Bz), $7.83(\mathrm{~m}, 2 \mathrm{H}, \mathrm{Bz}), 7.60(\mathrm{~m}, 1 \mathrm{H}, \mathrm{Bz}), 7.52(\mathrm{~m}, 2 \mathrm{H}, \mathrm{Bz}), 7.45(\mathrm{~m}, 3 \mathrm{H}, \mathrm{Bz}), 6.03(\mathrm{~d}, J=4.3 \mathrm{~Hz}, 1 \mathrm{H}$, $\left.\mathrm{H}^{\prime}\right), 5.34\left(\mathrm{~s}, 1 \mathrm{H}, \mathrm{OCH}_{2} \mathrm{O}\right), 5.25\left(\mathrm{~d}, J=6.0,4.3 \mathrm{~Hz}, 1 \mathrm{H}, \mathrm{H}^{\prime}\right), 5.12\left(\mathrm{~s}, 1 \mathrm{H}, \mathrm{OCH}_{2} \mathrm{O}\right), 5.01(\mathrm{dd}, J=6.1,1.9$ $\left.\mathrm{Hz}, 1 \mathrm{H}, \mathrm{H}^{\prime}\right), 4.53\left(\mathrm{~m}, 1 \mathrm{H}, \mathrm{H} 4^{\prime}\right), 4.00\left(\mathrm{dd}, J=12.7,1.9 \mathrm{~Hz}, 1 \mathrm{H}, \mathrm{H} 5^{\prime}\right), 3.84\left(\mathrm{dd}, J=12.6,2.5 \mathrm{~Hz}, 1 \mathrm{H}, \mathrm{H}^{\prime \prime}{ }^{\prime}\right)$. ${ }^{13} \mathrm{C}$ NMR (126 MHz, $\mathrm{CDCl}_{3}$ ) $\delta: 170.5(\mathrm{C}=\mathrm{O}), 170.2(\mathrm{C}=\mathrm{O}), 152.2(\mathrm{C} 2), 150.9(\mathrm{C} 6), 150.5$ (C4), 142.6 (C8), $133.3(\mathrm{Bz}), 133.2(\mathrm{Bz}), 132.9(\mathrm{Bz}), 132.1(\mathrm{Bz}), 130.2(\mathrm{Bz}), 130.0(\mathrm{Bz}), 128.8(\mathrm{Bz}), 128.6(\mathrm{Bz}), 128.4(\mathrm{Bz}), 128.2$ (Bz), $127.4(\mathrm{Bz}), 124.3(\mathrm{C} 5), 97.0\left(\mathrm{OCH}_{2} \mathrm{O}\right), 92.2\left(\mathrm{C1}^{\prime}\right), 85.7\left(\mathrm{C}^{\prime}\right), 82.9\left(\mathrm{C2}^{\prime}\right), 81.8\left(\mathrm{C}^{\prime}\right), 63.0\left(\mathrm{C}^{\prime}\right)$. HRMS (ESI) $m / z:[\mathrm{M}+\mathrm{Na}]^{+}$calcd for $\mathrm{C}_{25} \mathrm{H}_{21} \mathrm{~N}_{5} \mathrm{O}_{6} \mathrm{Na}^{+} 510.1384$, found 510.1373 .

\section{Conclusions}

$\mathrm{Hg}$ (II) accelerates the cleavage of RNA phosphodiester linkages by as much as two orders of magnitude, comparable to other divalent transition metal ions. At least two $\mathrm{Hg}$ (II) ions seem to participate in the catalysis, again in line with results obtained with other metal ions. While the observed modest acceleration of isomerization can be explained in terms of electrophilic catalysis by the $\mathrm{Hg}$ (II) ions coordinated to the scissile phosphate and/or general base catalysis by a $\mathrm{Hg}$ (II) hydroxo ligand, the much more pronounced acceleration of cleavage suggests additional general acid catalysis by a $\mathrm{Hg}$ (II) aqua ligand. Together with the unique ability of $\mathrm{Hg}$ (II) to accelerate depurination, these findings make $\mathrm{Hg}$ (II) an interesting new addition to the repertoire of metal ions usable in the development of artificial nucleases. It is also worth pointing out that while the state-of-the-art artificial metallonucleases are 
coordination complexes, the high stability of $\mathrm{Hg}(\mathrm{II})$ — carbon bonds would allow the design of a novel class of essentially covalent metallanucleases.

Supplementary Materials: The following are available online at http://www.mdpi.com/2073-4344/10/2/219/s1, Figures S1-S17: Copies of ${ }^{31} \mathrm{P} \mathrm{NMR},{ }^{13} \mathrm{C}$ NMR and ${ }^{1} \mathrm{H}$ NMR spectra of compounds 1a, 2a, 3, 4 and 5; Figures S18-S21: HPLC trace of the product mixtures of the kinetic studies.

Author Contributions: Conceptualization, T.L.; methodology, T.L. and M.O.; validation, T.L. and M.O.; formal analysis, T.L. and M.O.; investigation, L.Y.S.; resources, T.L.; data curation, T.L., M.O. and L.Y.S.; writing-original draft preparation, L.Y.S.; writing - review and editing, T.L. and M.O.; visualization, T.L.; supervision, T.L. and M.O.; project administration, T.L.; funding acquisition, T.L. All authors have read and agreed to the published version of the manuscript.

Funding: This research was funded by the Academy of Finland, grant number 286478, and the Finnish National Agency for Education, grant number TM-19-11029.

Conflicts of Interest: The authors declare no conflict of interest. The funders had no role in the design of the study; in the collection, analyses, or interpretation of data; in the writing of the manuscript, or in the decision to publish the results.

\section{References}

1. Dallas, A.; Vlassov, A.V.; Kazakov, S.A. Principles of Nucleic Acid Cleavage by Metal Ions. In Artificial Nucleases; Zenkova, M.A., Ed.; Springer: Berlin/Heidelberg, Germany, 2004; pp. 61-88.

2. Lönnberg, T. Understanding Catalysis of Phosphate-Transfer Reactions by the Large Ribozymes. Chem. Eur. J. 2011, 17, 7140-7153. [CrossRef] [PubMed]

3. Forconi, M.; Herschlag, D. Metal ion-based RNA cleavage as a structural probe. Methods Enzymol. 2009, 468, 91-106. [PubMed]

4. Pyle, A.M. Ribozymes: A distinct class of metalloenzymes. Science 1993, 261, 709-714. [CrossRef] [PubMed]

5. Sigel, R.K.O.; Sigel, H. 3.21-Metal-Ion Interactions with Nucleic Acids and Their Constituents. In Comprehensive Inorganic Chemistry II, 2nd ed.; Reedijk, J., Poeppelmeier, K., Eds.; Elsevier: Amsterdam, The Netherlands, 2013; pp. 623-660.

6. Ghidini, A.; Murtola, M.; Strömberg, R. Oligonucleotide Based Artificial Ribonucleases (OBANs). DNA Supramol. Chem. Nanotechnol. 2014. [CrossRef]

7. Komiyama, M. Cut-and-paste of DNA using an artificial restriction DNA cutter. Int. J. Mol. Sci. 2013, 14, 3343-3357. [CrossRef]

8. Aiba, Y.; Sumaoka, J.; Komiyama, M. Artificial DNA cutters for DNA manipulation and genome engineering. Chem. Soc. Rev. 2011, 40, 5657-5668. [CrossRef]

9. Kuzuya, A.; Komiyama, M. Site-selective artificial ribonucleases and their applications. Curr. Org. Chem. 2007, 11, 1450-1459. [CrossRef]

10. Morrow, J.R.; Iranzo, O. Synthetic metallonucleases for RNA cleavage. Curr. Opin. Chem. Biol. 2004, 8, 192-200. [CrossRef]

11. Mikkola, S.; Lönnberg, T.; Lönnberg, H. Phosphodiester models for cleavage of nucleic acids. Beilstein J. Org. Chem. 2018, 14, 803-837. [CrossRef]

12. Ora, M.; Lönnberg, T.; Lönnberg, H. Thio Effects as a Tool for Mechanistic Studies of the Cleavage of RNA Phosphodiester Bonds: The Chemical Basis. In From Nucleic Acids Sequences to Molecular Medicine; Erdmann, V.A., Barciszewski, J., Eds.; Springer: Berlin/Heidelberg, Germany, 2012; pp. 47-65.

13. Harris, M.E. Identification and Characterization of Metal Ion Coordination Interactions with RNA by Quantitative Analysis of Thiophilic Metal Ion Rescue of Site-Specific Phosphorothioate Modifications. In Handbook of RNA Biochemistry, 2nd ed.; Wiley-VCH: Weinheim, Germany, 2014; Volumes 1 and 2, pp. 285-299.

14. Forconi, M.; Herschlag, D. Use of phosphorothioates to identify sites of metal-ion binding in RNA. Methods Enzymol. 2009, 468, 311-333.

15. Frederiksen, J.K.; Piccirilli, J.A. Identification of catalytic metal ion ligands in ribozymes. Methods 2009, 49, 148-166. [CrossRef]

16. Christian, E.L. Identification and Characterization of Metal Ion Binding by Thiophilic Metal Ion Rescue. In Handbook of RNA Biochemistry; Wiley-VCH: Weinheim, Germany, 2008; pp. 319-344. 
17. Huang, P.-J.J.; Wang, F.; Liu, J. Cleavable Molecular Beacon for $\mathrm{Hg}^{2+}$ Detection Based on Phosphorothioate RNA Modifications. Anal. Chem. 2015, 87, 6890-6895. [CrossRef]

18. Sjöberg, S. Metal-Complexes with Mixed-Ligands 11 formation of ternary mononuclear and polynuclear mercury (II) complexes in system $\mathrm{Hg}^{2+}-\mathrm{Cl}-\mathrm{OH}$-potentiometric study in $3.0 \mathrm{M}(\mathrm{Na}) \mathrm{ClO}_{4}, \mathrm{Cl}$ media. Acta Chem. Scand. 1977, 31, 705-717. [CrossRef]

19. Lönnberg, H. Mechanisms for the solvolytic decompositions of nucleoside analogs.4. The effect of metal-ions on the acidic hydrolysis of 9-(1-ethoxyethyl) purine. Acta Chem. Scand. 1980, 34, 703-708. [CrossRef]

20. Almer, H.; Stawinski, J.; Strömberg, R.; Thelin, M. Synthesis of diribonucleoside phosphorothioates via stereospecific sulfuration of H-phosphonate diesters. J. Org. Chem. 1992, 57, 6163-6169. [CrossRef]

21. Järvinen, P.; Oivanen, M.; Lönnberg, H. Interconversion and phosphoester hydrolysis of $2^{\prime}, 5^{\prime}$-and 3',5'-dinucleoside monophosphates: Kinetics and mechanisms. J. Org. Chem. 1991, 56, 5396-5401. [CrossRef]

22. Simpson, R.B. Association Constants of Methylmercuric and Mercuric Ions with Nucleosides. J. Am. Chem. Soc. 1964, 86, 2059-2065. [CrossRef]

23. Leroy, J.L.; Guéron, M. Demonstration of different complexation modes between cobalt and 5' AMP, by direct NMR observation of the low-temperature complex. Biochimie 1982, 64, 297-299. [CrossRef]

24. Leroy, J.L.; Guéron, M. Demonstration and characterization of two complexes of cobalt(II) to mononucleotides by phosphorus-31 and proton NMR. J. Am. Chem. Soc. 1986, 108, 5753-5759. [CrossRef]

25. Collins, A.D.; Demeester, P.; Goodgame, D.M.L.; Skapski, A.C. Site of metal-ion binding in a nickel derivative of adenosine 5'-monophosphate-X-ray study. Biochim. Biophys. Acta 1975, 402, 1-6. [CrossRef]

26. Chapman, W.H.; Breslow, R. Selective Hydrolysis of Phosphate Esters, Nitrophenyl Phosphates and UpU, by Dimeric Zinc Complexes Depends on the Spacer Length. J. Am. Chem. Soc. 1995, 117, 5462-5469. [CrossRef]

27. Wall, M.; Hynes, R.C.; Chin, J. Double Lewis Acid Activation in Phosphate Diester Cleavage. Angezw. Chem. Int. Ed. 1993, 32, 1633-1635. [CrossRef]

28. Liu, S.D.; Hamilton, A. Rapid and highly base selective RNA cleavage by a dinuclear Cu(II) complex. Chem. Commun. 1999, 587-588. [CrossRef]

29. Iranzo, O.; Elmer, T.; Richard, J.P.; Morrow, J.R. Cooperativity between Metal Ions in the Cleavage of Phosphate Diesters and RNA by Dinuclear Zn(II) Catalysts. Inorg. Chem. 2003, 42, 7737-7746. [CrossRef] [PubMed]

30. Feng, G.; Mareque-Rivas, J.C.; Williams, N.H. Comparing a mononuclear Zn(ii) complex with hydrogen bond donors with a dinuclear $\mathrm{Zn}$ (ii) complex for catalysing phosphate ester cleavage. Chem. Commun. 2006, 1845-1847. [CrossRef]

31. Feng, G.; Natale, D.; Prabaharan, R.; Mareque-Rivas, J.C.; Williams, N.H. Efficient Phosphodiester Binding and Cleavage by a ZnII Complex Combining Hydrogen-Bonding Interactions and Double Lewis Acid Activation. Angew. Chem. Int. Ed. 2006, 45, 7056-7059. [CrossRef]

32. Linjalahti, H.; Feng, G.; Mareque-Rivas, J.C.; Mikkola, S.; Williams, N.H. Cleavage and Isomerization of UpU Promoted by Dinuclear Metal Ion Complexes. J. Am. Chem. Soc. 2008, 130, 4232-4233. [CrossRef]

33. Korhonen, H.; Mikkola, S.; Williams, N.H. The Mechanism of Cleavage and Isomerisation of RNA Promoted by an Efficient Dinuclear Zn2+ Complex. Chem. Eur. J. 2012, 18, 659-670. [CrossRef] [PubMed]

34. Breslow, R.; Huang, D.L. Effects of metal ions, including $\mathrm{Mg} 2+$ and lanthanides, on the cleavage of ribonucleotides and RNA model compounds. Proc. Natl. Acad. Sci. USA 1991, 88, 4080. [CrossRef] [PubMed]

35. Oivanen, M.; Ora, M.; Almer, H.; Strömberg, R.; Lönnberg, H. Hydrolytic Reactions of the Diastereomeric Phosphoromonothioate Analogs of Uridylyl $\left(3^{\prime}, 5^{\prime}\right)$ uridine: Kinetics and Mechanisms for Desulfurization, Phosphoester Hydrolysis, and Transesterification to the 2',5'-Isomers. J. Org. Chem. 1995, 60, 5620-5627. [CrossRef]

36. Norman, D.G.; Reese, C.B.; Serafinowska, H.T. 2' ,3'-O-Methylene derivatives of ribonucleosides. Synthesis 1985, 1985, 751-754. [CrossRef]

37. Busca, P.; Etheve-Quelquejeu, M.; Valéry, J.-M. Synthesis of 2'-O,3'-O bicyclic adenosine analogues using ring closing metathesis. Tetrahedron Lett. 2003, 44, 9131-9134. [CrossRef]

(C) 2020 by the authors. Licensee MDPI, Basel, Switzerland. This article is an open access article distributed under the terms and conditions of the Creative Commons Attribution (CC BY) license (http://creativecommons.org/licenses/by/4.0/). 